\title{
PEMBUKTIAN DALAM PERSPEKTIF HUKUM LINGKUNGAN
}

\author{
Yusuf Eko Nahuddin \\ Fakultas Hukum Universitas Merdeka Malang \\ Jl. Terusan Raya Dieng No. 62-64 Malang \\ yusuf.eko@unmer.ac.id
}

\begin{abstract}
This writing aims to know how the evidences in the perspective of environmental law that contains several aspects of the law dimension both civic and criminal in the provisions of environmental law about the evidence is known or added to the provisions of other evidence, as regulated in Article 96 letter $f$ Management and Protection Environmental Act Number 32 of 2009 which in explained that the other means of evidence, which includes; information uttered, transmitted, received, or stored electronically, magnetically, optically, and/or otherwise; and or evidence of data, recordings, or readable, viewable, and audible information that can be issued with and / or without the assistance of any means, whether contained on paper, any physical object other than paper, or electronically recorded. This is to provide an illustration that the evidence in the perspective of environmental law has experienced a significant development to calibrate the evidentiary process which is certainly different from the provisions in Article 184 of the Criminal Procedure Code (Criminal Procedure Code) in the hope that in the case of environmental law can be easier uncover environmental-related crimes by law enforcement officials.
\end{abstract}

Keywords: Environmental Law, Proof, Evidence.

\begin{abstract}
ABSTRAK
Penulisan ini bertujuan untuk mengetahui bagaimana pembuktian dalam prespektifhukum lingkungan yang mengandung beberapa aspek dimensi hukum baik secara keperdataan maupun secara pidana yang dalam ketentuan hukum lingkungan tentang alat buktinya dikenal atau ditambahkan dengan ketentuan alat bukti lain, sebagaiamana yang diatur dalam Pasal 96 huruff Undang-Undang Pengelolaan dan Perlindungan Lingkungan Hidup (UUPPLH) Nomor 32 Tahun 2009 yang dalam penjelasanya dijelaskan bahwa yang dimaksud dengan alat bukti lain, yaitu meliputi; informasi yang diucapkan, dikirimkan, diterima, atau disimpan secara elektronik, magnetik, optik, dan/atau yang serupa dengan itu; dan atau alat bukti data, rekaman, atau informasi yang dapat dibaca, dilihat, dan didengar yang dapat dikeluarkan dengan dan/atau tanpa bantuan suatu sarana, baik yang tertuang di atas kertas, benda fisik apa pun selain kertas, atau yang terekam secara elektronik. Hal ini untuk memberikan suatu gambaran bahwa pembuktian dalam prespektif hukum lingkungan telah mengalami perkembangan yang cukup siknifikan untuk mengkaver proses pembuktian yang tentunya berbeda dengan ketentuan dalam Pasal 184 KUHAP (Kitab Undang-Undang Hukum Acara Pidana) dengan harapan dalam pembuktian perkara tentang hukum lingkungan bisa mempermudah mengungkap kejahatan yang berhubungan dengan lingkungan hidup oleh aparat penegah hukum.
\end{abstract}

Kata kunci: Hukum Lingkungan, Pembuktian, Alat bukti. 
Manusia adalah merupakan makhluk hidup yang secara kodrati mempunyai akal rasa dan karsa yang tetunya diciptakan sebagai penyiimbang keberlangsungan alam semesta ini (Hadin Muhjad, 2015, 3). Manusia dengan akalnya tentu mampu memanfaatkan segala potensi yang dimiliki oleh alam ini untuk dimanfaatkan sebagaimana mestinya dalam rangka pemenuhan kebutuhan hidupnya, dengan tak terabaikanya tindakan prefentif dalam upaya menangulangi dampak dari akibat proses eksploitasi sumber daya alam yang mereka eksploitasi. Karena tidak kita pungkiri bahwa sumberdaya alam tentunya menjadi sumber utama untuk kita manfaatkan hasilnya dalam bentuk apapun sesuai dengan potensinya, sehingga alam harus tetap seimbang dan lestari.

Selanjutnya perkembangan dan mobilitas manusia di era moderen saat ini semakin tinggi yang berakibat permasalahan dalam kehidupan bermasyarakat semakin kompleks. Manusia kini bagaikan makhluk yang hanya ingin serba praktis dalam segala hal dalam hidupnya khususnya dalam upaya pemenuhan kebutuhan hidupnya. Hal ini tentunya menjadi peluang tersendiri dengan semakin menjamurnya berbagai pembangunan industri dan upaya eksploitasi sumber daya alam guna pemenuhan kebutuhan tanpa di imbangi dengan upaya pencegahan terhadap dampak yang ditimbulkan baik secara material maupun dampak sosialnya.

Kondisi demikan, tentu tidak hanya kita temukan di kota-kota besar saja, saat ini justru kota-kota kecil yang notabene masyarakatnya kurang respon dengan dampak yang diakibatkan oleh pembangunan industri dan eksploitasi sumber daya alam malah sudah semakin mejamur dan justru dianggap sebagai tempat yang strategis karena masyarakat mudah untuk dibodohi baik itu mengenai hak-haknya maupun terhadap dampak limbahnya yang tentunya masyarakat tidak merasa bahwa dia justru menjadi korbannya.

Fakta- fakta akan kondisi sosial masyarakat yang kena dampaknya oleh berbagai kegiatan industri maupun kegiatan ekpoitasi sumber daya alam kini bukan lagi menjadi rahasia umum, sebut saja PT. Lapindo Brantas, Sidoarjo yang karena ekploitasinya terhadap sumber daya alam yang ada menjadi salah satu penyebab menyemburnya lumpur lapindo yang kini lebih dikenal dengan lumpur sidoarjo, siapa yang menjadi korban lagilagi adalah masyarakat, rakyat yang menjadi korban tempat tinggalnya kini rata dengan lumpur, kerugian dalam bentuk materiil bahkan immateril jelas mereka rasakan yang sampai saat ini juga belum terselesaikan baik terkait dengan ganti rugi maupun hak-hak yang lainya lantas menjadi pertanyaan dimana rasa keadilan sosial bagi seluruh rakyat indonesia yang kita banga-bangakan sebagaimana yang menjadi bagian sila dari pancasila kita dasar falsafah bangsa ini.

Itu salah satu contoh kerugian yang dialami oleh kita terhadap eksploitasi dan pembangunan berbagai industri yang tanpa memperhatikan dan mengupayakan terhadap dampak lingkunganya. Padahal berdasarkan Umdang-Undang Dasar 1945 telah dengan tegas mengamanatkan bahwa hak atas lingkungan atau tempat tinggal sebagai hak subjektif atau hak individual. Hak tersebut sudah masuk dalam kelompok hak asasi manusia sebagai mana yang telah diatur dalam Pasal 28 H Ayat (1), substansi hak atas lingkungan hidup yang baik dan sehat, sebagaimana yang dirumuskan dalam Pasal 28 H Ayat 1 Undang- Undang Dasar 1945 yang selanjutnya ditegaskan lagi dalam Pasal 3 huruf $g$ dan Pasal 65 Ayat (1) UUPPLH 2009 Pasal 3 huruf g berbunyi“" perlindungan dan pengelolaan lingkungan hidup bertujuan menjamin pemenuhan dan perlindungan hak atas lingkungan hidup sebagai bagian dari hak asasi manusia. Dan selanjutnya Pasal 65 Ayat (1) UUPPLH 2009 berbunyi sebagaimana berikut" setiap orang berhak atas lingkugan hidup yang baik dan sehat sebagai bagian dari hak asasi manusia.

Ditegaskan kembali lebih lanjut dalam konstruksi Undang-Undang No 39 tahun 1999 tentang hak asasi manusia, dalam Undang- Undang 


\section{Pembuktian dalam Perspektif Hukum Lingkungan}

YusufEko Nahuddin

ini hak atas lingkungan ditegaskan kembali dalam satu bab tersendiri yakni bab III tentang hak manusia dan kebebasan dasar manusia, dimana bagian kesatu terkait dengan hak untuk hidup. Konsekuensi dari konstruksi hukum yang menempatkan hak tersebut sebagai bagian dari hak untuk hidup maka baik menurut kosntitusi Pasal $28 \mathrm{H}$ maupun dalam aturan khusus Undang-undang No 39 tahun 1999 tentang HAM, tentunya hak tersebut diatas termasuk hak asasi manusia, karena sifatnya yang asasi tersebut maka melekat dalam setiap individu-individu tanpa terkecuali yang tidak dapat dikurangi dalam keadaan maupun situasi apapun dan juga oleh siapapun. Dengan demikian jelas secara aturan hak untuk hidup dan berada pada lingkungan yang baik dan sehat adalah merupakan hak yang mutlak harus dihormati oleh semua orang dan maupun badan hukum (public maupun private).

Jelas bahwa dalam segi hukum aturan telah mengcover sedemikian sehigga dalam tujuan idealisnya tidak ada kelompok masyarakat atau manusia yag termarginalkan baik oleh aturan hukumnya maupun oleh keadaan sosial masyarakat. Namun yang menjadi persoalanya adalah bahwa kondisi pencemaran lingkungan yang diakibatkan oleh subjek hukum baik privat maupun publik masih sering sekali kita jumpai merugikan masyarakat yang berada dilingkungan industri maupun yang berada di wilayah atau lahan eksploitasi.

Sehinga penulis cukup tergugah untuk menuliskan sebuah makalah yang tentunya kami khususkan dalam upaya represif terhadap dampak lingkungan yang diakibatkan oleh perusahaan atau jenis eksploitasi apapun yang berdampak dan merugikan lingkunagan untuk itu penulis mangangkat makalah dengan judul "Pebuktian Dalam Prespektif Hukum Lingkungan" untuk menjawab persoalan bagaimana pembuktian dalam penyelesaian persoalan lingkungan prespektif hukum lingkungan yang meliputi dua dimensi penyelesaian hukum yakni melalui dimensi hukum pidana dan dimensi hukum perdata.

\section{Pembahasan}

Pengertian pembuktian pada umumnya adalah ketentuan-ketentuan yang berisi penggarisan dan pendoman tentang cara-cara yang dibenarkan Undang-undang membuktikan kesalahan yang didakwakan kepada terdakwa (M. Yahya Harahap, 2005. 273), Pembuktian juga merupakan ketentuan yang mengatur alat-alat bukti yang di benarkan undang-undang yang boleh dibenarkan oleh hakim untuk membuktikan kesalahan yang didakwakan, persidangan pengadilan yang berlagsung tidak boleh di pergunakan dengan sesuka hati dan semena-mena tanpa adanya dasar hukum yang jelas. Bahwa pada dasarnya proses penyelesaian perkara pidana mulai dari penyidikan sampai putusan akhir diucapkan di muka umum persidangan oleh majelis hakim adalah berupa kegiatan yang berhubungan dengan pembuktian atau membuktikan. Walaupun hukum pembuktian perkara pidana terfokus pada proses kegiatan pembuktian di sidang pengedilan, namun sesungguhnya proses membuktikan sudah ada dan dimulai pada saat penyidikan, bahkan pada saat penyelidikan, suatu perkerjaan awal dalam menjalankan proses perkara pidana oleh Negara (Adami Chazawi, 2011, 9).

Pengertian pembuktian menurut hukum acara pidana yaitu ketentuan yang membatasi sidang pengadilan dalam usaha mencari dan mempertahankan kebenaran. Baik hakim, penentuan umum, terdakwa terdakwa atau penasehat hukum, semua terikat pada ketentuan tat cara penilaian alat bukti yang ditentuakan Undang-undang tidak boleh leluasa bertindak dengan caranya sendiri dalam menilai pembuktian, dalam menilai pembuktian, dalam mempergunakan alat bukti, tidak boleh bertentangan dengan Undang-undang. 
Terdakwa tidak bisa leluasa mempertahankan sesuatu yang dianggapnya benar di luar ketentuan yang telah digariskan undang-undang. Terutama bagi majelis hakim, harus benar-benar sadar dan camat menilai dalam mempertimbangkan kekuatan pembuktian yang ditemukan selama pemeriksaan persidangan. Jika majelis halim hendak meletakkan kebenaran yang ditemukan dalam keputusan yang akan dijatuhkan, kebenaran itu harus di uji dengan alat bukti, dengan cara dan kekuatan pembuktian yang melekat pada setiap alat bukti, dengan cara dan kekuatan pembuktian yang melekat pada setiap alat bukti yang di temukan sehingga dapat menghindari kesalahan yang bisa menyebabkan ketidakadilan.

Proses pembuktian hakikatnya memang lebih dominan pada sidang pengadilan guna menemukan kebenaran meteriil akan peristiwa yang akan terjadi dan memberikan keyakinan kepada hakim tentang kejadian tersebut sehingga hakim dapat memberikan putusan yang tidak memihak. Adapun pembuktian dan alat-alat bukti dan proses pembuktian terhadap aspek-aspek sebagai berikut:

a. Perbuatan-perbuatan manakah yang dapat dianggap terbukti.

b. Apakah telah terbukti, bahwa terdakwa bersalah atau tidak atas perbutan-perbuatan yang didakwakan kepadanya.

c. Delik apakah yang dilakukan sehubungan dengan perbuatan-perbuatan itu.

d. Pidana apakah yang harus dijatuhkan kepada terdakwa (Martimah Prodjo, 2001, 99).

\section{Macam-Macam Alat Bukti}

Di dalam suatu perkara yang ada di persidangan mejelis hakim dalam memutuskan suatu perkara mencari dan meletakkan kebenaran yang akan di jatuhkan, harus berdasarkan pada alat bukti yang telah ditentukan oleh undang-undang sebagaimana dalam Pasal 184 Ayat (1) KUHAP, macam-macam alat terbukti itu adalah sebagai berikut: a. Keterangan Saksi

Keterangan saksi yang di atur dalam KUHAP Pasal 185 Ayat (1) terdapat berbagai macam ketentuan yaitu sebagai berikut:

1) Keterangan saksi sebagai alat bukti ialah apa yang saksi nyatakan di sidang pengadilan.

2) Keterangan seorang saksi saja tidak cukup untuk membuktikan bahwa terdakwa bersalah terhadap perbuatan yang di dakwakan kepadanya.

3) Ketentuan sebagaimana yang dimaksud dalam Ayat (2) tidak berlaku apabila disertai dengan suatu alat bukti yang sah laiannya.

4) Keterangan beberapa saksi yang berdiri sendiri-sendiri tentang suatu kejadian atau keadaan dapat di gunakan sebagai alat bukti yang sah apabila keterangan saksi itu ada hubungannya satu dengan yang lain sedemikian rupa, sehingga dapat membenarkan adanya suatu kejadian atau keadaan tertentu.

5) Baik pendapat maupun rekaan, yang diperoleh dari hasil pemikiran saja, bukan merupakan keterangan saksi.

6) Dalam menilai kebenaran keterangan seorang saksi, hakim harus dengan sungguh-sungguh memperhatikan

a) Persesuaian antara keterangan saksi satu dengan yang lain.

b) Persesuaian antara keterangan saksi dengan bukti lain.

c) Alasan yang mungkin dipergunakan oleh saksi untuk memberikan keterangan yang tertentu.

d) Cara hidup kesusilaan saksi serta segala sesuatu yang pada umumnya dapat mempengaruhi dapat tidaknya keterangan itu dipercaya.

7) Keterangan dari saksi yang tidak disumpah meskipun sesuai satu dengan yang 


\section{Pembuktian dalam Perspektif Hukum Lingkungan}

YusufEko Nahuddin

lain tidak merupakan alat namun apabila keterangan itu sesuai dengan keterangan dari saksi yang disumpah dapat dipergunakan sebagai tambahan alat bukti sah yang lain.

Sedangkan manurut ketentuan Pasal 185 Ayat (1) KUHAP, memberi batasan pengertian keterangan saksi dalam kapasitasnya sebagai alat bukti menerangkan, bahwa: "keterangan saksi sebagai alat bukti ialah apa yang saksi nyatakan di sidang pengadilan" melalui kajian teoritis dan praktek dapat disimpulkan bahwa menjadi seorang saksi merupakan kewajiban hukum bagi setiap orang, apabila seseorang dipanggil menjadi saksi tetapi menolak/tidak masuk hadir didepan persidangan, saksi tersebut agar dihadapkan dipersidangan (Pasal 159 Ayat (2) KUHAP).

Alat bukti keterangan saksi merupakan alat bukti yang palingan utama dalam perkara pidana, KUHAP telah memberikan batasan pengertian saksi adalah orang yang dapat memberikan keterangan guna kepetingan penyidikan, penuntuta, dan peradilan tentang suatu perkara yang ia dengar sendiri, di amelihat sendiri dan dia alami sendiri. Sedangkan keterangan adalah salah satu alat bukti dalam perkara pidana yang berupa keterangan dari saksi mengenai suatu peristiwa pidana yang berupa keterangan saksi mengenai suatu peristiwa pidana yang dia dengar sendiri, dia lihat sendiri dan dia alami sendiri dengan menyebut alasan dari pengetahuannya itu.

b. Keterangan Ahli

Sesuai dengan KUHAP Pasal 186 tertulis bahwa: keterangan ahli ialah apa yang seorang ahli nyatakan di sidang pengadilan. Pengertian keterangan ahli adalah adalah keterangan yang diberikan oleh seorang memiliki keahlian khusus tentang hal yang diperlukan membust terang suatu perkara pidana guna kepentingan pemeriksaan. Seorang ahli disini berbeda de- ngan keterangan korban yang harus memberikan keterangan dari seorang korban yang harus memberikan keterangan dari suatu yang ia dengar sendiri, ia lihat sendiri dan ia alami sendiri, sedangkan seorang ahli memberikan keterangan bukan mengenai keterangan dari sesuatu yang ia dengar sendiri, ia lihat sendiri dan ia alami sendiri melainkan mengenai halhal yang menjadi atau dibidang keahliannya yang ada hubungannya dengan perkara yang sedang diperiksa. Apa yang diterangakan saksi adalah hal mengenai kenyataannya atau fakta, tetapi yang diterangkan ahli adalah suatu perghargaan diri kenyataan dan atau kesimpulan atas penghargaan itu berdasarkan keahlian seseorang (Adami Chazawi, 2011, 41).

c. Surat

Alat bukti surat ini yang tercantum dalam KUHAP Pasal 187, yang tertulis demikian: "surat sebagaimana yang tersebut pada Pasal 187 KUHAP Ayat (1) huruf c dibuat atas jabatan atau dikuatkan dengan sumpah, adalah":

a) Berita acara dan surat lain dalam bentuk resmi yang dibuat oleh pejabat umum yang berwenang atau yang di bauat dihadapannya, yang memuat tentang kejadian atau keadaan yang di dengar, dilihat atau yang dialaminya sendiri, disertai dengan alasan yang jelas dan tegas tentang keterangannya itu.

b) Surat yang di buat menurut ketentuan peraturan perundang-undangan atau surat yang di buat oleh pejabat mengenal hak yang termasuk tata laksana yang menjadi tanggung jawabnya yang di peruntukkan bagi pembuktian sesuatu hal atau sesuatu keadaan.

c) Surat keterangan dari seorang ahli yang memuat pendapat berdasarkan keahliannya mengenai sesuatu hal atau sesuatu keadaan yang diminta secara resmi dari padanya. 
d) Surat lain yang hanya dapat berlaku jika ada hubungannya dengan isi dari alat-alat pembuktian yang lain.

Menurut ketentuan Undang-undang ini, surat yang dapat dinilai sebagai alat bukti yang sah ialah surat yang di buat atas sumpah jabatan atau surat yang dikuatkan dengan sumpah. Surat-surat resmi hanyalah yang diatur dalam Pasal 187 huruf a, b, c KUHAP. Sementara itu yang diatur dalam Pasal 187 huruf d KUHAP, termasuk surat biasa yang setiap hari bisa dibuat oleh seseorang. Surat-surat yang dimaksud dalam Pasal 187 huruf a, b, c KUHAP, memang sejak semula diperuntukkan untuk membuktikan sesuatu. Surat resmi yang dimaksdu Pasal 187 huruf a KUHAP, yaitu berita berita acara yang dibuat oleh pejabat umum yang berwenang atau yang dibuat dihadapannya, yang memuat keterangan tentang kejadian atau keadaan yang didengar, dilihat atau dialami sendiri.

Macam-macam surat resmi sebagaimana dimaksud Pasal 187 huruf a, b, c termasuk surat atau akta otentik. Surat atau akta disini terbagi menjadi 2 jenis yaitu acte ambetelijk, adalah akta otentik yang dibuat oleh pejabat umum, pembuatan akta otentik tersebut sepenuhnya merupakan kehendak dari pejabat umum tersebut dan acte partij adalah akta otentik yang dibuat para pihak di hadapan pejabat umum, pembuatan akta otentik tersebut sepenuhnya berdasarkan atas kehendak dari para pihak dengan bantuan pejabat umum sedangkan, Pasal 187 huruf d KUHAP termasuk surat biasa.

d. Petunjuk

Alat bukti pentunjuk ini sesuai dengan tertulis dalam KUHAP Pasal 188, yaitu tertulis demikian:

a) Petunjuk adalah perbuatan, kejadian atau keadaan, yang karena persesuaian, baik antara yang satu dengan yang lain, maupun denagn tindak pidana itu sendiri, me- nandakan bahwa telah terjadi suatu tindak pidana dan siapa pelakunya.

b) Petunjuka sebagaimana dalam Ayat (1) hanya dapat diperoleh dari:

1. Keterangan saksi

2. Surat

3. Keterangan terdakwa

c) Penilaian atas kekuatan pembuktian dari suatu petunjuk dalam setiap keadaan tertentu dilakukan oleh hakim dengan arif lagi bijaksana, setelah ia menggadakan pemeriksaan dengan penuh kecermatan kesaksamaan berdasarkan hati nurani.

Alat bukti petunjuk ini bukanlah alat bukti yang berdiri sendiri, melainkan suatu alat bukti bentukan hakim, hal itu tampak dari batasnya dalam ketentuan Pasal 188 Ayat (1). Oleh karena itu alat bukti petunjuk ini dapat berupa pemikiran atau pendapat hakim yang dibentuk dari hubungan atau persesuaian alat bukti yang ada dan dipergunakan dalam sidang, maka sifat subyektivitas hakim lebih dominan sehingga Pasal 188 Ayat (3) mengginggatkan hakim agar dalam menilai kekuatan alat bukti petunjuk dalam setiap keadaan tertentu harus dilakukan dengan arif bijaksana, setelah hakim memriksa dengan cermat dan seksama yang di dasarkan hati nurani.

Unsur alat bukti petunjuk yaitu yang pertama, adanya perbuatan, kejadian, keadaan yang bersesuaian. kedua, ada dua persesuaian ialah persesuaian antara masing-masing perbuatan, kejadian, dan atau keadaan tindak pidana yang didakwakan. Yang ketiga, dengan adanya persesuaian yang demikian itu menandakan atau menunjukkan adanya dua hal in casu kejadian, ialah pertama menunjukan bahwa benar telah terjadi suatu tindak pidana dan kedua menunjukkan siapa pelakunya. Alat bukti petunjuk ini hanya dapat dibentuk melalui tiga alat bukti, yaitu: keterangan saksi, surat, keterangan terdakwa. 


\section{Pembuktian dalam Perspektif Hukum Lingkungan}

YusufEko Nahuddin

e. Keterangan terdakwa

Alat bukti selanjutnya adalah keteranga terdakwa yang diatur dalam KUHAP Pasal 189, yang tertulis sebagaimana berikut:

a) Keteranga terdakwa ialah apa yang terdakwa nyatakan di sidang tentang perbuatan yang ia lakukan atau yang ia ketahui sendiri atau alami sendiri.

b) Keteranga terdakwa yang diberikan di luar persidangan dapat digunakan untuk membantu menemukan bukti di sidang. Asalkan keterangan itu di dukung oleh suatu alat bukti yang sah sepanjang mengenai hal yang di dakwakan kepadanya.

c) Keterangan terdakwa hanya dapat digunakan terhadap dirinya sendiri.

d) Keterangan terdakwa saja tidak cukup untuk membuktikan bahwa ia bersalah melakukan perbuatan yang didakwakan kepadanya, melainkan harus disertai dengan alat bukti yang lain.

Alat bukti keteranga terdakwa merupak urutan terakhir dalam Pasal 184 Ayat (1) KUHAP, tidak semua keterang terdakwa mengandung nilai pembuktian. Dari ketentuan Pasal 189 didaptkan syarat-syarat yang harus dipenuhi agar keterangan terdakwa mengandung nilai pembuktian, yaitu:

a) Keteranga terdakwa haruslah dinyatakan dimuka sidang pengadilan.

b) Isi dari keterangan terdakwa haruslah mengenai tiga hal, ialah pertama perbuatan yang dilakukan terdakwa, kedua segala hal yang diketahuinya sendiri dan ketiga kejdian yang dialamia sendiri.

c) Nilai keterangan terdakwa hanya berlaku sebagai bukti untuk dirinya sendiri.

d) Keterangan terdakwa saja tidak cukup untuk membuktikan bahwa dirnya bersalah melakukan tindak pidana, melainkan harus ditambah dengan alat bukti lain.
Hal-hal diataslah yang pada umumnya sebagai dasar hukum pembuktian secara normatif yang harus dipahami sebagai landasan umumnya dalam pembuktian, namun yang perlu dipahami sebagaimana asas lex spesialis derogat lex generalis maka dalam ketentuan khusus yang mengatur terkait tindak pidana hukum lingkungan juga diatur bagaimana pembuktian dan seperti apa teknis pelaksananya siapa yang paling berwenang.

\section{Pembuktian dalam Penegakan Hukum Lingkungan}

Tindak pidana pelangaran terhadap perlindungan dan pengelolaan lingkungan hidup UUPPLH menjadikan satu antara penyidikan dengan pembuktian yaitu berada dalam bab XIV dimana dalam bagian satu terkait dengan penyidikan yang berwenang serta wewenangya dalam malakukan penyidikan terhadap indikasi adaya pelangaran terhadap pelindungan dan penggelolaan lingkungan hidup (M. Taufik Makarno, 2011, 241).

Adapun terkait dengan yang berwenang dalam melakukan proses penyidikan, maka sebagaimana Undang-undang khusus seperti yang lainnya maka yang berwenang untuk melakukan proses pnyidikan adalah penyidik pejabat polisi republik indonesia dan pejabat pegawai negeri sipil tertentu yang berada di lingkungan instansi pemerintahan yang lingkup tugasnya dan tanggung jawabnya dibidang perlindungan dan pengelolaan lingkungan hidup.

UUPPLH adalah merupakan aturan terhadap tindak pidana khusus yang tentunya secara penyelesaianpun berbeda dengan tindak pidana pada umumnya khususnya dalam proses penyidikan sampai dengan pembuktian. Dalam hal pembuktian sekilas hampir sama dengan pembuktian pada umumnya yang diatur didalam KUHAP namun bentuk aturan khususnya dalam hal pembuktian karena dampak yang ditimbulkan dari 
tindakan pelangaran hukum terhadap perlindungan dan pengelolaan lingkungan hidup sangat kompleks serta berdampak besar terhadap kondisi sosial masyarakat dalam berbagai aspek.

Oleh karena itu maka menurut hemat kami bahwa pelangaran ini termasuk pelanggaran luar biasa, sehingga berdasarkan UUPPLH dalam pembuktianya diatur khusus dalam undang-undang tersebut. Sebagaimana berdasarkan Pasal 96 UUPPLH dalam bagian kedua tentang pembuktian diakatakan bahwa alat bukti yang sah dalam tuntutan tindak pidana lingkungan hidup terdiri dari: a) keterangan saksi; b) keterangan ahli; c) surat; d) petunjuk; e) keterangan terdakwa dan/atau; f) alat bukti lain, termasuk alat bukti yang diatur dalam peraturan perundang-undangan.

Berdasarkan hal diatas maka secara umum berbicara terkait dengan alat-alat bukti dalam pembuktian hampir sama dengan atauran pada umumnya. Namun yang mejadi perbedan adalah bahwa ada alat bukti lain diluar alat bukti pada umumnya tersebut yang diamsukan. Hal tersebut sebagaimana yang ditegaskan dalam huruf Pasal 96 huruf f yang memberikan kelenturan terhadap uandang-undang untuk mengatur sehingga tidak tejadi kekosongan dalam menyelesaikan sebuah kasus yang secara tingkatan kasusnya adalah kasus kejahatan yang luar biasa.

Berdasarkan penjelasan terkait dengan alat bukti lain, sebagaiamana yang diatur dalam Pasal 96 huruf $f$ dijelaskan dalam penjelasan bahwa yang dimaksud dengan alat bukti lain, yaitu meliputi; informasi yang diucapkan, dikirimkan, diterima, atau disimpan secara elektronik, magnetik, optik, dan/atau yang serupa dengan itu; dan atau alat bukti data, rekaman, atau informasi yang dapat dibaca, dilihat, dan didengar yang dapat dikeluarkan dengan dan/atau tapa bantuan suatu sarana, baik yang tertuang di atas kertas, benda fisik apa pun selain kertas, atau yang terekam secara elektronik, tidakterbatas pada tulisan, suara, atau gambar, peta, rancangan, foto atau sejenisnya, huruf, tanda, angka, simbol, atau perporasi yang memiliki makna atau yang dapat dipahami atau dibaca.

Dengan demikian maka perluasan alat bukti dalam hukum perlindungan dan pengelolaan lingkungan hidup, menurut hemat penulis cukup tepat sebagai antisipasi terhadap kekakuan hukum yang terkadang aturan yang ada yang jusru membatasi penyelesaian dalam setiap kasus. Dengan semangat dalam melindungi hak asasi manusia tentunta hal itu sangat diperlukan dengan tidak membatasi sebuah alat bukti tentunya menjadi sebuah terobosan terseniduri dalam politik sistem hukum nasional ini.

Sehinga tinggal upaya para penegak hukum untuk berani menyelesaikan kasus perlangaran terhaap lingkungan atau tidak, karena kebanyakan kasus-kasus yang berdampak terhadap lingkungan itu disebabkan oleh kelompok-kelompok elit yang mempunyai pengaruh dan akses yang baik terhadap birokrasi pemerintahan karena mau tidak mau dalam proses apapun yang berhubungan dengan lingkungan harus meminta izin kepada pemerintahan yang berwenang dalam hal ini bisa jadi pemerintahan provinsi maupun pemerintaha kabupaten atau kota. Serta karena dampaknya yang dahsyat tersebut di imbangi dengan keuntunganya yang lumayan mengiurkan tidak jarang adanya indikasi keterlibatan orang birokrasi pemerintahan dalam melakukan kejahatan tersebut.

Dengan demikian maka kembali lagi kepada mental parat penegak hukum berani atau tidak dalam menyelesaikan kasus tersebut yang cukup komples punya rentetan panjang seperti mata rantai yang saling berkaitan dalam satu pelangaran terhadap lingkungan hidup tersebut. Sehinga dengan pembuktian yang memberikan ruang yang lebih luas dalam hal pembukian maka diharapkan mampu untuk bener-bener menyelesaikan perkara pida terhadap lingkungan hidup sampai tuntas. Baik itu aktor intelektualnya, aktor pelaksana maupun aktor-aktor lainya. 
Terkait dengan pengertian dari jenis-jenis alat bukti tersebut secara umum telah disebutkan diawal secara gamblang dan menyeluruh. Terkait dengan alat bukti yang dimaksud degan UUPPLH Ayat 96 huruf $\mathrm{f}$ meliputi segala informasi yang dapat menjadi bukti dalam sidang pembuktian. Hal itu yang menjadi unsur pembeda dari jenis pelangaran pada umumnya dalam hal pembuktian. Oleh sebab itu maka secara teori dibutuhkan keterpaduan antara para aparat penegak hukum dalam menyelesaikan kasus pelangaran lingkungan hidup ini.

\section{Kesimpulan}

UUPPLH merupakan aturan terhadap tindak pidana khusus yang tentunya secara penyelesaianya berbeda dengan tindak pidana pada umumnya khususnya dalam proses penyidikan sampai dengan pembuktian. Pembuktian berdasarkan Pasal 96 UUPPLH dalam bagian kedua tentang pembuktian diakatakan bahwa alat bukti yang sah dalam tuntutan tindak pidana lingkungan hidup terdiri dari: a) keterangan saksi; b) keterangan ahli; c) surat; d) petunjuk; e) keterangan terdakwa dan/ atau; f) alat bukti lain, termasuk alat bukti yang diatur dalam peraturan perundang-undangan penjelasan terkait dengan alat bukti lain.

Pasal 96 huruf $\mathrm{f}$ dijelaskan dalam penjelasan bahwa yang dimaksud dengan alat bukti lain, yaitu meliputi; informasi yang diucapkan, dikirimkan, diterima, atau disimpan secara elektronik, magnetik, optik, dan/atau yang serupa dengan itu; dan atau alat bukti data, rekaman, atau informasi yang dapat dibaca, dilihat, dan didengar yang dapat dikeluarkan dengan dan/atau tapa bantuan suatu sarana, baik yang tertuang di atas kertas, benda fisik apa pun selain kertas, atau yang terekam secara elektronik, tidakterbatas pada tulisan, suara, atau gambar, peta, rancangan, foto atau sejenisnya, huruf, tanda, angka, simbol, atau perporasi yang memiliki makna atau yang dapat dipahami atau dibaca.

\section{DAFTAR PUSTAKA}

Buku

Chazawi, Adami, 2011, Hukum Pembuktian Tindak Pidana Korupsi, Cet. 1, Penerbit Bayumedia Publishing, Malang.

Harahap, M. Yahya, 2005, Pembahasan Permasalahan Dan Penerapan KUHAP; Pemeriksaan Sidang Pengadilan, Bandiang, Kasasi, Dan Peninjauan Kembali, Cet. 6, Edisi 2, Penerbit Sinar Grafika, Jakarta.

Muhjad, Hadin, 2015, Hukum Lingkungan, Cet. 1, Genta Publishing, Yogjakarta.

Makarno, M. Taufik, 2011, Aspek-aspek Hukum Lingkungan, Cet. II, Indeks, Jakarta.

Prodjo, Martimah, 2001, Penerapan Pembuktian Terbalik Dalam Delik Korupsi, Penerbit Mandar Maju, Bandung.

\section{Peraturan Perundang-undangan}

Kitab Undang-undang Hukum Acara Pidana.

Undang-undang No 32 Tahun 2009 Tentang Perlindungan dan pengelolaan lingkungan hidup. 